\title{
Interpretation of Seasonal Variation of Metals and Abiotic Properties in a Tropical Lake Using Multivariate Analysis and MINTEQA2 Program
}

\author{
Wagner J. Barreto, ${ }^{1 \dagger}$ Maira R. Ribeiro, ${ }^{11}$ Maria C. SolcI, ${ }^{* 2}$ Ieda S. SCARMinio, *2 \\ Jorge NozaKI, ${ }^{* 3}$ Elisabeth de OliveIRa, ${ }^{* 4}$ Sônia R. G. BARRETO ${ }^{* 5}$ \\ *1 Laboratory of Environmental Physical Chemistry, Department of Chemistry, Londrina State University, \\ 86051-990, Londrina, Paraná, Brazil \\ *2 Department of Chemistry, Londrina State University, 86051-990, Londrina, Paraná, Brazil \\ *3 Department of Chemistry, Maringa State University, 87020-900, Maringa, Paraná, Brazil \\ *4 Institute of Chemistry, University of São Paulo, São Paulo, São Paulo, Brazil \\ *5 Graduate Program in Ecology of Aquatic and Continental Environments, Maringa State University, \\ Av. Colombo, 5790, Maringa, PR, Brazil
}

\begin{abstract}
The hydrological cycle of Lake Ipê and the principal parameters that could affect its abiotic parameters and its metal (Fe, $\mathrm{Mn}$, and $\mathrm{Cd}$ ) concentrations were investigated. A detailed study of seasonal variations using Principal Components Analysis (PCA) for the most relevant metals (Fe, Mn and Cd) was performed, assisted by the MINTEQA2 geochemical equilibrium program using 15 water abiotic parameters. The abiotic variables and metals in the lake were governed by the hydrological regimen of the Parana River and by the occurrence of occasional flood pulses and rainfall. The occurrence of cadmium is a concern; its presence could be due to industrial or agricultural activities or even to a natural geochemical process.
\end{abstract}

(Received August 13, 2004; Accepted October 7, 2004)

\section{Introduction}

The chemical composition of natural waters is determined by several sources. Many terrestrial aquatic organisms disturb the substratum (soil, sediment) in which they grow and live, extracting chemical substances from the environment and excreting others that may affect the chemistry of natural waters. Also human influence could influence this precarious equilibrium and cause important effects on the communities using the water resources. This work was the first to study systematically the water characteristics of Lake Ipê, where the water regimen is regulated by Itaipu (southwest-downstreams) and Ilha Solteira (northeast-upstreams) dams. The main tributary of the Parana River is the Tiete River coming from S. Paulo city, about $300 \mathrm{~km}$ upstreams. S. Paulo is the largest city of South America with over 10000000 inhabitants and its largest industrial park, with practically no treatment of domestic and industrial wastewaters. Several studies have been performed in the Tiete River basin, always upstream from the Ilha Solteira dam. However knowledge is lacking of the lake waters downstream from the dam.

The river-floodplain systems of tropical regions are submitted to very particular climate and environmental conditions, causing a remarkable temporal variation in the physical-chemical and biotic parameters. Alterations in these parameters are related mainly to changes in the hydrometrical levels, called "flood

† To whom correspondence should be addressed.

E-mail: barreto@uel.br pulse", ${ }^{1}$ having two phases, flood and drought. ${ }^{2,3}$ The seasonal behavior in a tropical flood plain region is controlled by factors different from those that act in temperate regions, where the determining parameters are temperature and photo-period. ${ }^{4}$

The objective of this study was to explain the seasonal variation of abiotic parameters and of the most important metals (Fe, Mn, and Cd) during a complete hydrological cycle of Lake Ipê (13 months) supported by Principal Components Analysis (PCA) and MINTEQA2 analysis.

\section{Experimental}

\section{Area of investigation}

The upper Parana basin occupies a vast area, over $802150 \mathrm{~km}^{2}$ in Brazilian territory where the Baia River, Curutuba Channel, and the Ivinheima River form, besides innumerable lagoons, water bodies that complete the drainage network of that region. ${ }^{5}$ Lake Ipê, MS, Brazil, which belongs to the Parana River plain, is located at the right bank of the Curutuba Channel (Fig. 1). The lake is in constant communication with the Curutuba Channel by means of a small, narrow channel, and its maximum depth varies from 1.5 to $3.0 \mathrm{~m}$ from low waters (LW) to high waters (HW). The lake area was determined as being 110764 $\mathrm{m}^{2}$ by measurements carried out by GPS. The lake was sampled at the deepest place which is at a depth of $270 \mathrm{~m}$, located at S $22^{\circ} 45^{\prime} 57^{\prime \prime}$ and $\mathrm{W} 53^{\circ} 26^{\prime} 38^{\prime \prime}$.

\section{Sampling and analytical methods}

A vertical profile of Lake Ipê was obtained by monthly water 


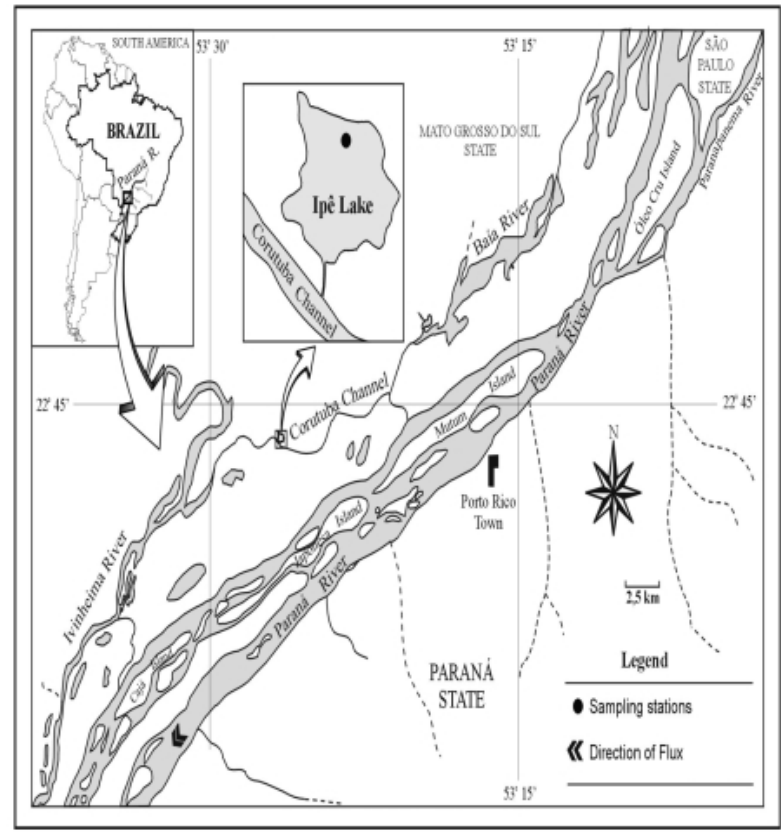

Fig. 1 Location of Parana River and Lake Ipê. The flow direction of the Parana River is from the northeast to the southwest, and the Ivinheima River is from the northwest to the southwest as shown. Lake Ipê is located at the right margin of the Curutuba Channel, between the Ivinheima and Baia Rivers, Mato Grosso do Sul, Brazil.

collections between June 1999 and June 2000 at the lake's deepest part (Fig. 1); in all 13 samples were taken. The samples were collected at intervals of $50 \mathrm{~cm}$ of water column with Van Dorn's bottle and stored in plastic mineral water bottles. The bottom samples were collected at $1.5 \mathrm{~m}$ in December 1999 and May 2000, at $2.5 \mathrm{~m}$ in July 1999 and March 2000, and at $2.0 \mathrm{~m}$ in the remaining months. The $\mathrm{pH}$ measurements (Hanna Instruments Model Hi 9321), water temperature, and DO (YSI52-YSI Corporation-USA field measurers), $\mathrm{pE}$ (Digimed Model $\mathrm{DM} / 10 \mathrm{pH} / \mathrm{ORP}$ ), and electrolytic conductivity (Hanna Instruments Model HI 8819N) were carried out at the place of collection at about 11 o'clock. No thermal stratification was observed at the moment of measurements. Alkalinity was determined by Gran titration. ${ }^{6}$

The water samples were filtered through a $0.45 \mu \mathrm{m}$ cellulose ester Millipore filter and placed in a "Millipore Sterifil Holder" type of filtration instrument with a stainless-steel suspender. The filters were washed with $500 \mathrm{~mL}$ ultra-pure water (MilliQ). The filtered water used for the nitrate, sulfate, and dissolved organic carbon (DOC) determinations was divided into 5 sub-samples for each determination, and stored in labeled $30 \mathrm{~mL}$ flasks.

Chlorophyll $a$ was determined with $200 \mathrm{~mL}$ of water and filtered under a light shelter, in triplicate and simultaneously. The chlorophyll $a$ concentration was obtained by spectrophotometry according to the methodology described by Lorenzen ${ }^{7}$ and Wetzel and Likens. ${ }^{6}$

Orthophosphate was determined in triplicate, with two analytical blanks; the standard addition technique was used. Phosphate was determined by the ascorbic acid reduction method. ${ }^{8}$ Particulate phosphorus (particulate P) was obtained from the difference between total and dissolved P.

The nitrate and sulfate concentrations were determined by ion chromatography with a conductivity suppression Sycam S 1100 chromatograph and a Sycam S3130 conductivity detector.
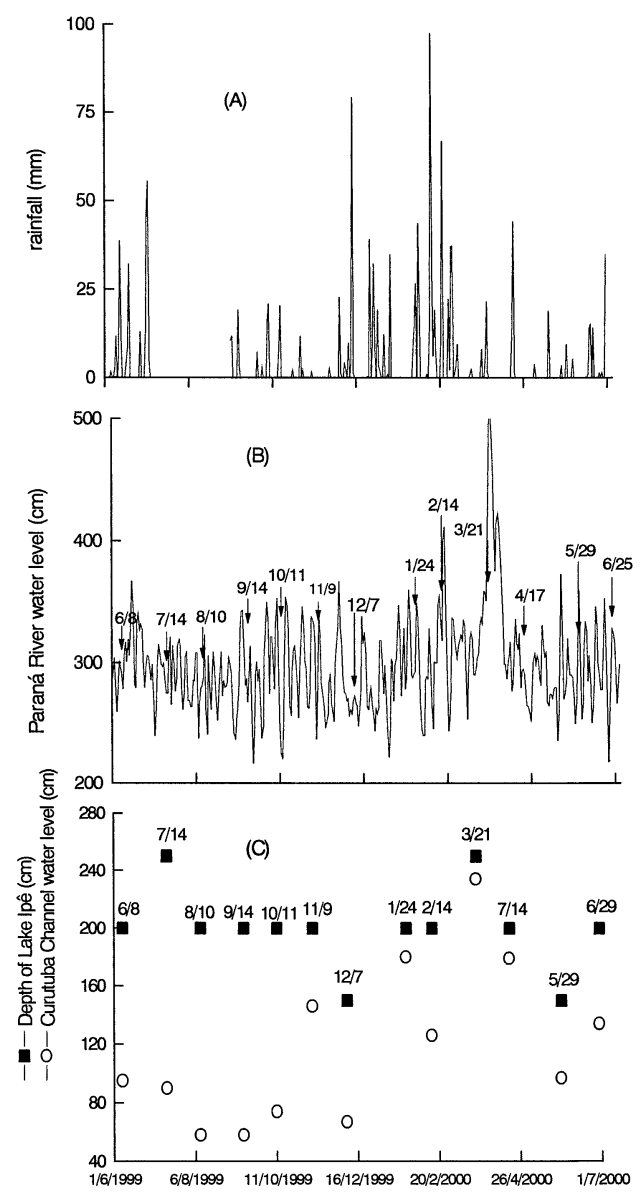

Fig. 2 Water levels and rainfall. (A) Daily rainfall $(\mathrm{mm})$ in the period from June/1999 and June/2000; (B) daily water levels (cm) of the Parana River at the city of Porto São José between June/1999 and June/2000; (C) lake depth (cm) at the moment of collection at the sampling point and water levels $(\mathrm{cm})$ of the Curutuba Channel at the entrance of Lake Ipê on the sampling date.

Sub-samples for the DOC determination were determined by a Shimadzu carbon analyzer Model TOC 5000A. Total phosphorous and sulfur were determined by atomic emission spectrometry with an induced argon plasma (ICP-AES) Spectroflame Spectro Analytical Instrument.

The water samples were filtered using a $0.45 \mu \mathrm{m}$ cellulose ester Millipore filter and placed in a "Millipore Sterifil Holder". In triplicate, the sub-samples of non-filtered and filtered water of each depth, accompanied by two blanks were preconcentrated to approximately $20 \mathrm{~mL}$ on a heating plate at $60^{\circ} \mathrm{C}$. The samples were transferred to $25 \mathrm{~mL}$ volumetric flasks, then completed with ultra-pure water for analysis by atomic emission spectrometry. The metals $(\mathrm{Fe}, \mathrm{Mn}$ and $\mathrm{Cd})$ present in non-filtered and acidified water samples were represented by total metal and those in filtered and acidified water samples by dissolved metal.

Multivariate analysis was applied to the experimental data using the ARTHUR computer program. ${ }^{9}$ The values of physical-chemical parameters and metal concentrations correspond to their arithmetic means. The columns were autoscaled to obtain variable values with zero means and variances equal to 1. Principal Components Analysis (PCA) and Pearson's 95\% confidence interval correlation coefficient calculations were applied to this matrix. ${ }^{9}$

Theoretical calculations of geochemical equilibrium were 

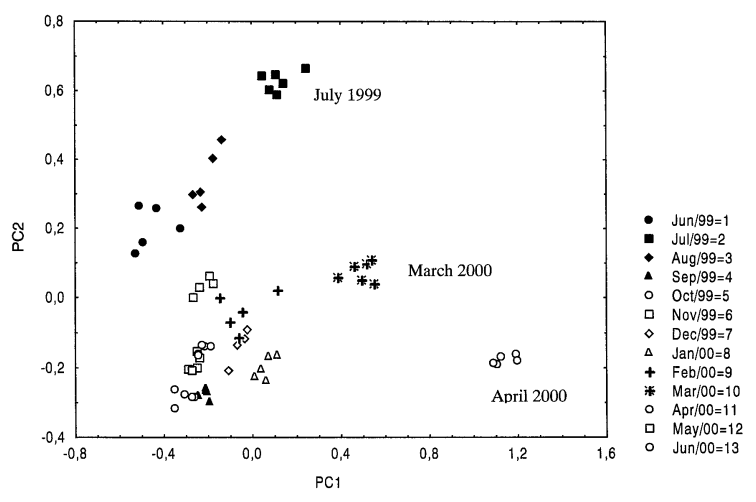

Fig. 3 Scores of the first two principal components (PC1 and PC2). PC1 and PC2 explained $72 \%$ of the total variance.

carried out by means of the MINTEQA2 computer program, ${ }^{10}$ adapted for the Windows Visual MINTEQ, version 1.03. ${ }^{11}$

\section{Results and Discussion}

Application of multivariate methods of analysis

The period of study from June 1999 to June 2000, was divided into two sub-periods, according to the Lake Ipê, Paraná River, and Curutuba Channel rainfall and water levels (Fig. 2).

The first sub-period of study, from June 1999 to December 1999 was characterized as LW. The second sub-period, called HW, started in January 2000 and continued until mid-April 2000. The months of May 2000 and June 2000 correspond to the next sub-period of LW. Figure 3 shows the first two principal components (PC1 and PC2) for water samples of both periods. Water samples collected in January and February 2000 (placed close to the origin of the graph) and especially those collected in March and April 2000 (placed on the lower right) are discriminated by PC1 from the other sampling months, confirming the presence of two sub-periods. It is interesting to note that December samples are more similar to those of the HW period than to those of the LW one.

Many of the variables studied contributed to the separation into two sub-periods, but the most relevant were orthophosphate, $\mathrm{Fe}$, dissolved total $\mathrm{P}, \mathrm{DOC}, \mathrm{Cd}$, and $\mathrm{Mn}$ concentrations. The dissolved $\mathrm{O}_{2}$ concentration was the main PC1 variable, 0.157, that clustered other sampling months into another group. The LW may be considered of greater hydrological stability, not exactly because of thermal stratification maintenance, since there is normally night circulation, but because of a scarcity of flood pulses. ${ }^{12}$ Such hydrological stability of Lake Ipê was disturbed in July 1999, perhaps influenced by the Ivinheima River.

Figure 2 shows that in July 1999 there was an increase in rainfall and in the water level of Lake Ipê, while there were practically no alterations on the water levels of the Parana River and the Curutuba Channel. In Fig. 3, the water samples collected in July 1999 can be seen to be discriminated along PC2 from the other samples classified in the LW period. This is due to the concentrations of $\mathrm{SO}_{4}{ }^{2-}$, dissolved $\mathrm{S}$ and $\mathrm{Mn}$ in filtered water samples.

This alteration may occur owing to localized rainfalls in July 1999 or may be influenced by the Ivinheima River, causing an increase in depth and flooding on the peatland next to the lake, such land being rich in organic matter in decomposition.

A careful multivariate statistical study was performed with the
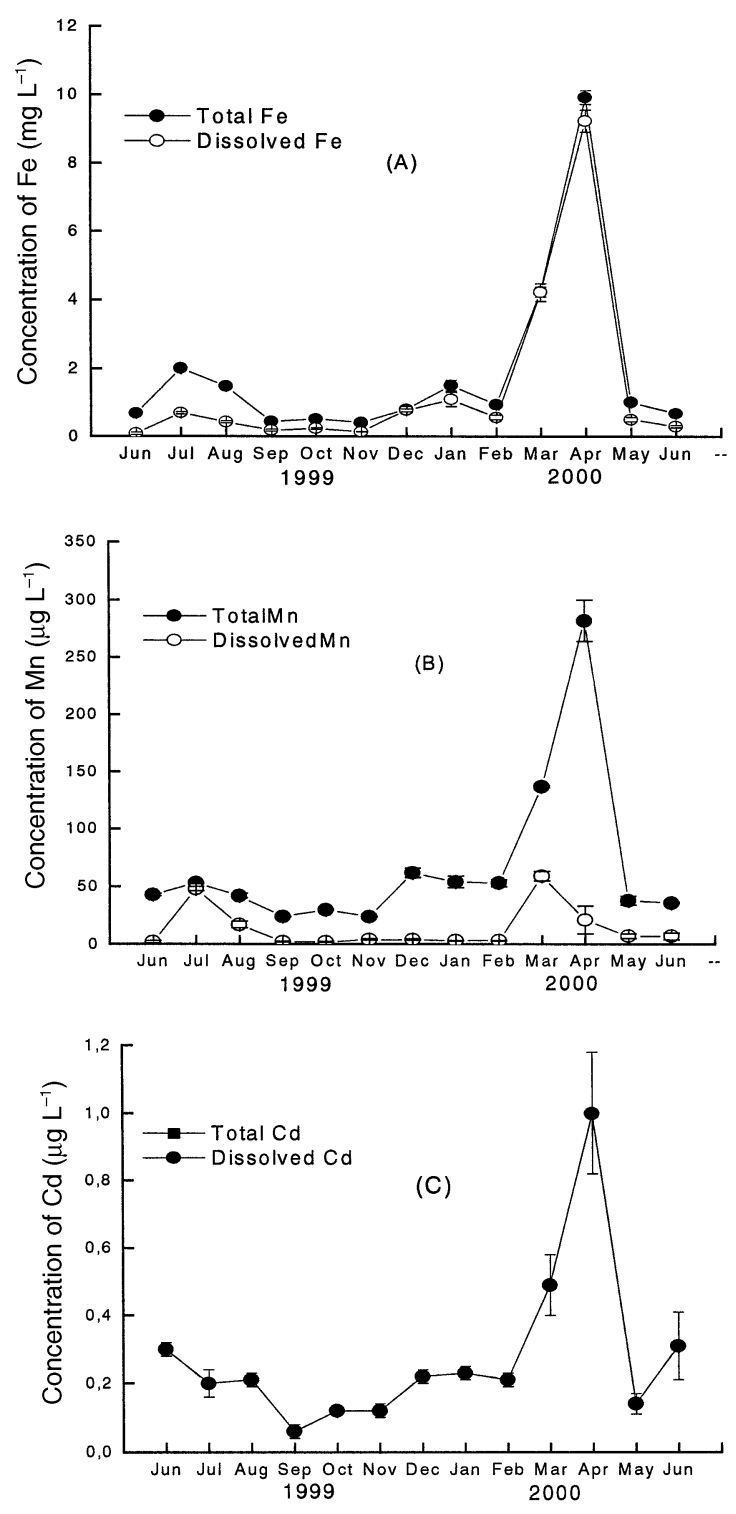

Fig. 4 Distributions of (A) Fe (mg L $\left.{ }^{-1}\right)$, (B) $\mathrm{Mn}\left(\mu \mathrm{g} \mathrm{L}^{-1}\right)$, and (C) $\mathrm{Cd}\left(\mu \mathrm{g} \mathrm{L}^{-1}\right)$ concentrations in waters of Lake Ipê from June 1999 to June 2000. Total metals: non filtered and acidified water. Dissolved metals: filtered and acidified water.

most relevant variables: ortho-phosphate, Fe, dissolved total $\mathrm{P}$, DOC, $\mathrm{Cd}$, and Mn concentrations, in order to understand the origins of the seasonal variations of the lake water.

\section{Abiotic variables}

In July 1999 (LW), the conductivity of the water column was $36.67 \mu \mathrm{S} \mathrm{cm}^{-1}$ and in April 2000 it was $54.20 \mu \mathrm{S} \mathrm{cm}-1$, so the conductivity is strongly controlled by the rainfall. The contribution of the transition metals in conductivity was mostly due to the high $\mathrm{Fe}^{2+}$ concentration of $0.69 \mathrm{mg} \mathrm{L}^{-1}$ in July 1999 and $9.26 \mathrm{mg} \mathrm{L}^{-1}$ in April 2000. The low level of dissolved oxygen was strongly correlated with the high $\mathrm{Fe}^{2+}$ concentration, as shown in Table 1 and Fig. 4.

Alkalinity presented values that oscillated between 166 and $285 \mu \mathrm{eq} \mathrm{L} \mathrm{L}^{-1}$; the seasonal variation was similar to that observed for conductivity. This was also verified by Thomaz et al. ${ }^{13}$ for the Parana and Ivinheima Rivers. The average Eh values between June 1999 and June 2000 were $230 \mathrm{mV}$, indicating mostly an aerobic environment. ${ }^{14}$ 
Table 1 Abiotic variables for Lake Ipê from June 1999 to June 2000

\begin{tabular}{|c|c|c|c|c|c|c|c|c|c|c|c|}
\hline $\begin{array}{l}\text { Month/ } \\
\text { year }\end{array}$ & $\mathrm{pH}$ & $\begin{array}{c}\text { Dissolved } \mathrm{O}_{2} / \\
\mathrm{mg} \mathrm{L}^{-1}\end{array}$ & $\begin{array}{l}\mathrm{DOC} / \\
\mathrm{mg} \mathrm{L}^{-1}\end{array}$ & $\begin{array}{c}\text { Chlorophyll } a / \\
\mu \mathrm{g} \mathrm{L}^{-1}\end{array}$ & $\begin{array}{c}\text { Ortho-P/ } \\
\mu \mathrm{g} \mathrm{L}^{-1}\end{array}$ & $\begin{array}{c}\text { Dissolved P/ } \\
\mu \mathrm{g} \mathrm{L}^{-1}\end{array}$ & $\begin{array}{l}\text { Total P/ } \\
\mu \mathrm{g} \mathrm{L}^{-1}\end{array}$ & $\begin{array}{l}\mathrm{NO}_{3}^{-/} \\
\mathrm{mg} \mathrm{L}^{-1}\end{array}$ & $\begin{array}{l}\mathrm{SO}_{4}^{2-/} \\
\mathrm{mg} \mathrm{L}^{-1}\end{array}$ & $\begin{array}{l}\text { Dissolved S/ } \\
\mathrm{mg} \mathrm{L}^{-1}\end{array}$ & $\begin{array}{l}\text { Total S/ } \\
\mathrm{mg} \mathrm{L}^{-1}\end{array}$ \\
\hline \multirow[t]{2}{*}{ Jun/99 } & 6.42 & 6.48 & 6.23 & 13.29 & 1.0 & 3.0 & 13.0 & 0.39 & 0.48 & 0.24 & 0.30 \\
\hline & $(0.04)$ & $(0.41)$ & $(0.57)$ & $(1.32)$ & $(0.6)$ & $(0.5)$ & $(1.0)$ & $(0.16)$ & $(0.04)$ & $(0.04)$ & $(0.02)$ \\
\hline \multirow[t]{2}{*}{ Jul } & 5.73 & 2.58 & 14.81 & 4.56 & 9.0 & 17.0 & 25.0 & 0.72 & 3.47 & 1.48 & 1.68 \\
\hline & $(0.03)$ & $(0.16)$ & $(0.38)$ & $(0.29)$ & $(3.0)$ & $(1.2)$ & $(1.0)$ & $(0.13)$ & $(0.11)$ & $(0.04)$ & $(0.04)$ \\
\hline \multirow[t]{2}{*}{ Aug } & 6.05 & 6.41 & 11.41 & 13.47 & 3.0 & 9.0 & 18.0 & 0.41 & 1.05 & 0.61 & 0.61 \\
\hline & $(0.04)$ & $(0.49)$ & $(0.51)$ & $(1.38)$ & $(1.0)$ & $(0.8)$ & (1.0) & $(0.06)$ & $(0.22)$ & $(0.02)$ & $(0.02)$ \\
\hline \multirow[t]{2}{*}{ Sep } & 6.96 & 9.22 & 4.03 & 24.57 & 4.0 & 4.0 & 10.0 & 0.34 & 0.99 & 0.50 & 0.50 \\
\hline & $(0.10)$ & $(0.48)$ & $(0.13)$ & (2.16) & $(0.3)$ & $(0.4)$ & $(0.5)$ & $(0.03)$ & $(0.03)$ & $(0.01)$ & $(0.01)$ \\
\hline \multirow[t]{2}{*}{ Oct } & 6.93 & 10.9 & 4.43 & 26.07 & 3.0 & 3.0 & 12.0 & 0.43 & 0.90 & 0.25 & 0.42 \\
\hline & $(0.04)$ & $(1.39)$ & $(0.15)$ & $(0.84)$ & (0.6) & $(0.2)$ & $(0.4)$ & $(0.10)$ & $(0.06)$ & $(0.01)$ & $(0.02)$ \\
\hline \multirow[t]{2}{*}{ Nov } & 6.91 & 6.90 & 4.06 & 17.19 & 1.0 & 3.0 & 11.0 & 0.14 & 0.79 & 0.38 & 0.44 \\
\hline & $(0.04)$ & $(0.37)$ & $(0.72)$ & $(1.12)$ & (0.6) & (0.3) & (0.4) & $(0.06)$ & $(0.07)$ & $(0.01)$ & $(0.01)$ \\
\hline \multirow[t]{2}{*}{ Dec } & 6.59 & 4.05 & 5.72 & 24.09 & 4.0 & 11.0 & 12.0 & 0.38 & 0.71 & 0.31 & 0.35 \\
\hline & $(0.06)$ & $(0.06)$ & $(0.24)$ & $(0.81)$ & (1.0) & $(0.9)$ & (1.0) & $(0.26)$ & $(0.03)$ & 0.04 & 0.01 \\
\hline \multirow[t]{2}{*}{ Jan/00 } & 6.67 & 6.16 & 6.27 & 20.02 & 4.0 & 7.0 & 12.0 & 0.96 & 0.39 & 0.31 & 0.31 \\
\hline & $(0.02)$ & $(0.81)$ & $(0.23)$ & $(0.81)$ & $(1.0)$ & $(0.9)$ & (2.0) & $(0.42)$ & $(0.02)$ & $(0.02)$ & $(0.01)$ \\
\hline \multirow[t]{2}{*}{ Feb } & 6.90 & 1.78 & 5.14 & 13.92 & 5.0 & 8.0 & 13.0 & 1.19 & 0.61 & 0.29 & 0.35 \\
\hline & $(0.04)$ & $(0.50)$ & $(0.98)$ & $(2.01)$ & (1.0) & (1.2) & (1.0) & $(0.34)$ & $(0.02)$ & $(0.01)$ & $(0.02)$ \\
\hline \multirow[t]{2}{*}{ Mar } & 6.57 & 2.78 & 19.01 & 11.66 & 14.0 & 37.0 & 37.0 & 0.76 & 0.64 & 0.47 & 0.55 \\
\hline & $(0.05)$ & $(2.20)$ & $(0.76)$ & $(2.65)$ & (1.0) & (1.0) & $(8.0)$ & $(0.38)$ & $(0.09)$ & $(0.01)$ & $(0.02)$ \\
\hline \multirow[t]{2}{*}{ Apr } & 6.54 & 2.34 & 38.42 & 33.36 & 27.0 & 51.0 & 54.0 & 2.15 & 0.27 & 0.45 & 0.54 \\
\hline & $(0.02)$ & $(0.18)$ & $(1.02)$ & $(2.10)$ & $(2.0)$ & (0.9) & (1.0) & $(1.10)$ & $(0.02)$ & $(0.01)$ & $(0.00)$ \\
\hline \multirow[t]{2}{*}{ May } & 6.62 & 3.28 & 5.81 & 11.37 & 3.0 & 5.0 & 13.0 & 0.43 & 0.75 & 0.39 & 0.41 \\
\hline & $(0.04)$ & $(0.15)$ & $(0.48)$ & $(0.90)$ & $(0.3)$ & (1.4) & $(1.0)$ & $(0.05)$ & $(0.06)$ & $(0.01)$ & $(0.01)$ \\
\hline \multirow[t]{2}{*}{ Jun } & 6.71 & 5.92 & 6.38 & 17.11 & 5.0 & 6.0 & 12.0 & 0.49 & 0.52 & 0.31 & 0.31 \\
\hline & $(0.05)$ & $(0.34)$ & $(0.25)$ & $(1.81)$ & (1.5) & $(0.6)$ & (1.0) & $(0.04)$ & $(0.05)$ & $(0.01)$ & $(0.01)$ \\
\hline
\end{tabular}

( ) Standard deviation of the arithmetic means of the three depths.

Dissolved organic carbon (DOC), dissolved oxygen (DO) and $p H$

The annual distribution of DOC concentration presents two maxima verified in July 1999 (LW) (14.81 $\left.\mathrm{mg} \mathrm{L}^{-1}\right)$ and in April 2000 (38.42 $\left.\mathrm{mg} \mathrm{L}^{-1}\right)$, Table 1. Due to the high values of the relation $\mathrm{A}(254 \mathrm{~nm}) / \mathrm{DOC}\left(\mathrm{g} \mathrm{L}^{-1}\right)$ [absorbance at (254 $\mathrm{nm}) /$ dissolved organic carbon] in July $1999\left(65.08 \mathrm{~L} \mathrm{~g} \mathrm{~g}^{-1}\right)$, April 2000 (42.67 $\mathrm{L} \mathrm{g} \mathrm{g}^{-1}$ ), and March 2000 (36.66 L g $\left.{ }^{-1}\right),{ }^{15}$ Lake Ipê could be characterized, at least during those months, as predominantly fulvic. ${ }^{16}$ The increase in DOC in July 1999 was probably due to the lixiviation of the bank regions and flooding of the lake banks with the vegetal organic matter decomposition that occurred in a semi-closed environment.

The decrease in DO in June 1999 was attributed to localized rainfalls (Fig. 2) or perhaps the influence of Ivinheima River, which contributed to the increase in DOM (dissolved organic matter), in the inner part of the lake. Such an increase in allochthonous $\mathrm{OM}$ in an aquatic ecosystem causes higher oxygen consumption due to microbial decomposition. ${ }^{17}$ The high value of the standard deviation that occurred in March 2000 in the water column was due to accentuated differences in DO concentrations between the lake surface $\left(5.60 \mathrm{mg} \mathrm{L}^{-1}\right)$ and in depths over $1 \mathrm{~m}\left(1.40 \mathrm{mg} \mathrm{L}^{-1}\right)$. This mean that DO was close to anoxia in the deepest layers of the water column. The sharp $\mathrm{pH}$ decrease in July 1999 (5.73), in relation to the other months of LW (6.42), was probably due to the increase in OM or the decrease of dissolved oxygen, brought on by the rainfall pulse in that month and the consequent decomposition, causing an increase in fulvic acid.

\section{Phosphorus, sulfur, chlorophyll a and nitrate}

The nitrate concentration showed a gradual increase in HW due to the water influx of the Paraná River. To reinforce this assumption, $\mathrm{NO}_{3}{ }^{-}$did not show a correlation higher than 0.700 with any variables contained in the matrix. The ortho-P reached its maximum in April 2000, $27 \mu \mathrm{g} \mathrm{L}^{-1}$ (HW) (Table 1). In LW (except for July 1999) 67\% of the total P presented itself as particulate $\mathrm{P}$ (Table 1). In that period, the chlorophyll $a$ (algal biomass) presented an inverse relation with ortho-P, DOC and $\mathrm{A}(254 \mathrm{~nm}) / \mathrm{DOC}\left(\mathrm{g} \mathrm{L}^{-1}\right)$. In June 1999, the relation $\mathrm{A}(254$ $\mathrm{nm}) / \mathrm{DOC}\left(\mathrm{g} \mathrm{L}^{-1}\right)$ was $27 \mathrm{~L} \mathrm{~g}^{-1}$ (the water of the lake presented a light color), and in (July 1999) the relation observed was $65 \mathrm{~L}$ $\mathrm{g}^{-1}$, due to localized rainfalls that carried organic allochthonous material into the lake, which could be visually perceived because of water darkening (brown water). ${ }^{15}$ Wetzel $^{18}$ and Jones $^{19}$ also presented higher total $\mathrm{P}$ values in dark waters compared to light-colored waters.

From August until September 1999, the lake water gradually lost that color, and the values of $\mathrm{A}(254 \mathrm{~nm}) / \mathrm{DOC}\left(\mathrm{g} \mathrm{L}^{-1}\right)$ decreased (11.46 $\mathrm{L} \mathrm{g} \mathrm{g}^{-1}$ and $\left.35.74 \quad \mathrm{~L}^{-1}\right)$, as did the concentrations of total $\mathrm{P}$, ortho- $\mathrm{P}$, and $\mathrm{DOC}$ becoming practically constant until December 1999. In the period from June 1999 to June 2000, Lake Ipê presented total P values between 10 and $30 \mu \mathrm{g} \mathrm{L}^{-1}$ (Table 1), except in March and April 2000, characterized as meso-eutrophic. March 2000 (total P = $37 \mu \mathrm{g} \mathrm{L}^{-1}$ ) and April (total $\mathrm{P}=54 \mu \mathrm{g} \mathrm{L}^{-1}$ ) were characterized as eutrophic (total $\mathrm{P}=30-100 \mu \mathrm{g} \mathrm{L}^{-1}$ ). ${ }^{18}$

The $\mathrm{SO}_{4}^{2-}$ concentrations were higher than $50 \%$ of the dissolved total $\mathrm{S}$ in practically all months of the period studied and the concentration of $\mathrm{SO}_{4}{ }^{2-}$ remained below $1 \mathrm{mg} \mathrm{L}^{-1}$, except in July 1999, with $3.47 \mathrm{mg} \mathrm{L}^{-1}$. The entry of OM into the lake in July 1999, coming from the terrestrial areas and the decomposition of OM with sulfur, such as amino acids, and the effluents coming from tannery industries may have been the cause of increasing $\mathrm{SO}_{4}{ }^{2-}$. 
Metals

Iron. Figure 4A shows the distribution of total and dissolved $\mathrm{Fe}$ concentrations. Two maxima were observed in the distribution, one in July 1999: $2.016 \pm 0.057 \mathrm{mg} \mathrm{L}^{-1}(\mathrm{LW})$ and the other in April 2000: $9.949 \pm 0.203 \mathrm{mg} \mathrm{L}^{-1}(\mathrm{HW})$. A maximum was observed in the distribution of dissolved Fe in July 1999: 0.691 $\pm 0.033 \mathrm{mg} \mathrm{L}^{-1}$ and a very accentuated one in April 2000: 9.262 $\pm 0.324 \mathrm{mg} \mathrm{L}^{-1}$, perhaps due to soil erosion.

About $50 \%$ of $\mathrm{Fe}$ was in the dissolved form during $\mathrm{LW}$, except when an increase in the lake depth occurred, due to the rainfalls in July 1999, when only 34\% of total Fe was in the dissolved form. Therefore, the rainfalls in July 1999 carried mostly particulate $\mathrm{Fe}$ into the lake, which may come from the soil and/or as debris and biomass components. MINTEQA2 theoretical calculations showed that Fe was not complexed with organic matter during LW, due to the physical-chemical conditions presented by the lake. In the HW period, considerable increases occurred in the concentrations of total and dissolved $\mathrm{Fe}$. The highest percentage of dissolved $\mathrm{Fe}$ occurred in March and April 2000, due to the low level of DO in water, reaching about $100 \%$. The low level of dissolved oxygen is helpful to the reduction of $\mathrm{Fe}^{3+}$ compounds to more soluble $\mathrm{Fe}^{2+}$. This indicates that the loads of particulate $\mathrm{Fe}$ present in waters of the river suffered total sedimentation along its slow course until they reached the lake. Dissolved $\mathrm{Fe}$ represents one of the variables with the highest loading (0.26618) on PC1 that discriminates the sampled months. Theoretical calculations showed that, during HW, the dissolved $\mathrm{Fe}$ species and their respective percentages were: $\mathrm{Fe}^{2+}(>99 \%)$, $\mathrm{FeHCO}_{3}{ }^{+} \quad(0.276-0.423 \%), \quad \mathrm{FeOH}^{+} \quad(0.145-0.342 \%)$, $\mathrm{FeSO}_{4}(\mathrm{aq})(0.048-0.124 \%)$ and also indicated that $\mathrm{Fe}$ did not complex with organic matter under the physical-chemical conditions to which the system was submitted. However, studies of the correlations among all the variables determined high values between dissolved $\mathrm{Fe}^{2+}$ and DOC (0.947). This high correlation may be justified by the presence of hydrated $\mathrm{Fe}^{2+}$ or $\mathrm{Fe}^{2+}$ complexed with organic matter, being able to pass through the $0.45 \mu \mathrm{m}$ filter, in lake waters coming from the Parana River.

Borg $^{20}$ reported that the concentration of filterable $\mathrm{Fe}$ in natural waters is, in general, much higher than that established by $\mathrm{Fe}(\mathrm{III})$ solubility in aqueous solution, especially in humus waters, which may be explained by the occurrence of colloidal complexes of humus: $\mathrm{Fe}$ and the reduction of $\mathrm{Fe}^{3+}$ to $\mathrm{Fe}^{2+}$, possibly associated with organic compounds. Dissolved Fe also correlated highly with orthophosphate $(0.955)$ and dissolved total P (0.941), confirmed by the theoretical equilibrium calculations, which showed the presence of dissolved chemical species $\mathrm{FeHPO}_{4}(\mathrm{aq})(0.044 \%)$ and $\mathrm{FeH}_{2} \mathrm{PO}_{4}{ }^{+}(0.015 \%)$ in the environment.

Manganese. The concentrations of total Mn did not suffer relevant variations in the period between June 1999 and February 2000 (Fig. 4B).

The highest increments started in March 2000, together with the increase in the water level of the Parana River and the lake depth. The concentrations of dissolved $\mathrm{Mn}$ reached two maxima in July 1999: $48 \pm 2 \mu \mathrm{g} \mathrm{L}^{-1}$ (LW) and March 2000: 59 $\pm 4 \mu \mathrm{g} \mathrm{L}^{-1}$, which extended until April 2000: $21 \pm 10 \mu \mathrm{g} \mathrm{L}^{-1}$ (HW). In the remaining months, the concentrations of dissolved Mn remained close to zero, with a value of $3.7 \pm 1.7 \mu \mathrm{g} \mathrm{L}^{-1}$ for $n=9$. The principal components analysis discriminated the dissolved Mn variable of PC2 (0.22899) in July 1999 from the others in the LW period. In July 1999, $90 \%$ of the total Mn appeared in the dissolved form. Results of theoretical calculations during LW showed that manganese was found in soluble forms, $\mathrm{Mn}^{2+}(99.21 \%), \mathrm{MnSO}_{4}$ (aq) (0.49\%), and $\mathrm{MnHCO}_{3}{ }^{+}(0.31 \%)$ for the complete set of variables that identified the water samples in July 1999. The presence of these dissolved Mn species in lake waters could be due to superficial flow and/or to atmospheric precipitation, because of the rainfalls localized in the lake region during that month.

In August 1999, the dissolved Mn decreased to $16.5 \pm 2.9 \mu \mathrm{g}$ $\mathrm{L}^{-1}$, probably due to the sedimentation or the use of dissolved Mn by the biota and, by November 1999, it constituted only about $10 \%$ of the total $\mathrm{Mn}$. The highest concentrations of total Mn in HW occurred in March $\left(137 \pm 1 \mu \mathrm{g} \mathrm{L}^{-1}\right)$ and April 2000 $\left(282 \pm 18 \mu \mathrm{g} \mathrm{L}^{-1}\right)$. In that period, the lake suffered a continuous and rising influx of waters from the Parana River, with a predominance of particulate Mn concentration, in March (60\%) and in April 2000 (92\%). Thus, it may be concluded that the manganese present in the lake, coming from the Parana River, was in the form of $\mathrm{MnO}_{2}$. The concentration of dissolved $\mathrm{Mn}$ remained similar to the value in LW, except in March 2000, when it increased to $43 \%$ of the total Mn concentration. Such increases in $\mathrm{Mn}^{2+}$ concentration could have been attributed to the presence of manganese in waters of the Paraná River, in association with inorganic molecules, as suggested by Gibbs, ${ }^{21}$ who studied samples of filtered water $(0.45$ and $0.10 \mu \mathrm{m})$ from the Amazon River, Brazil.

Theoretical calculations showed that there is no possibility of $\mathrm{Mn}^{2+}$ complexing with dissolved organic matter under the lake physical-chemical conditions in March and April 2000. Furthermore, about $99 \%$ of the Mn appeared in the form of $\mathrm{Mn}^{2+}, 0.50 \%$ as $\mathrm{MnHCO}_{3}{ }^{+}$, and $0.1 \%$ as $\mathrm{MnSO}_{4}(\mathrm{aq})$, being coherent with the correlations among the variables studied, which showed that there is no significant correlation between dissolved Mn and DOC (0.399).

Cadmium. Cadmium appeared only in the dissolved form between June 1999 and June 2000 (Fig. 4C), consistent with Borg's ${ }^{21}$ findings, who included $\mathrm{Cd}$ among the elements that appear mostly in its dissolved form in lakes. In HW, the highest concentrations of dissolved Cd started in March $(0.50 \pm 0.05 \mu \mathrm{g}$ $\left.\mathrm{L}^{-1}\right)$ and reached its maximum in April $2000(0.95 \pm 0.05 \mu \mathrm{g}$ $\mathrm{L}^{-1}$ ). The correlation among all variables was high for dissolved $\mathrm{Cd}$ and $\mathrm{DOC}$ (0.91), and for PC1, the dissolved $\mathrm{Cd}$ variable (0.2589) was important in discriminating the water samples collected in March and April 2000. Theoretical calculations for March and April 2000 showed that Cd species were found $100 \%$ in the dissolved form and the important forms present with their respective percentages for the samples were: $\mathrm{Cd}^{2+}$ (90.85 - 86.64\%) and DOM-Cd (8.86-13,11\%).

\section{Conclusions}

It was observed that the lake is polymictic, presenting mostly an aerobic environment, and that the abiotic variables and metals were governed by the hydrological regimen of Paraná River. PCA discriminated between two statistically distinct periods: LW (low waters) and HW (high waters). The parameters with the greatest loading for discrimination were ortho $\mathrm{P}, \mathrm{Fe}$, dissolved total $\mathrm{P}$, DOC, $\mathrm{Cd}$, and $\mathrm{Mn}$. The occurrence of occasional flood pulses affected the lake water composition in the drought period, due to the sudden entry of allochthonous matter and water. The decrease of DO, increase of DOC, and sudden decrease in $\mathrm{pH}$ in July 1999 were strongly correlated with the high concentration of soluble $\mathrm{Fe}^{2+}$. In HW, the level of Paraná River increased gradually during four months, causing a concomitant increase in the concentrations of total and dissolved metals $\left(\mathrm{Fe}^{2+}, \mathrm{Mn}^{2+}, \mathrm{Cd}^{2+}\right)$ in the lake waters. $\mathrm{An}$ 
alternative interpretation for cadmium presence is that the Paraná River, or localized rains, could have a strong influence on the underground water level in the Lake Ipê region in these particular periods, and so the high trace metal contents in the Lake Ipê periods could be a natural geochemical process and not the result of the human pollution. The hypothesis is that metals were moistened in the turf but they could have been solubilized and brought up into the lake by the underground water when the Paraná River rose.

We may conclude that the variation of the physical chemical parameters, except for $\mathrm{Cd}$, could be interpreted as a result of the natural hydrological cycle characterized by high and low waters, and occasionally affected by flood pulses.

\section{Acknowledgements}

The authors thank Dr. Keiko Takashima and Dr. Roy E. Bruns for text revision and CNPq for financial support. They also thank Dr. Sidnei M. Thomaz and Dr. Thomaz A. Pagioro for their assistance for DOC determination. Sônia R. G. Barreto thanks CAPES/PICDT/UEL for a scholarship. Maira R. Ribeiro thanks PIBIC/CNPq/UEL for a scholarship.

\section{References}

1. W. J. Junk, P. B. Bayley, and R. E. Sparks, Can. Spec. Publ. Fish. Aquat. Sci., 1989, 106, 110.

2. J. J. Neiff, Intersciencia, 1990, 15, 424.

3. S. M. Thomaz, M. C. Roberto, and L. M. Bini, "A foodplain area of high Parana river. Physical, biological and socioeconomic aspects", ed. A. E. A. M. Vazzoler, A. A. Agostinho, and N. S. Hahn, 1997, EDUEM, Maringá, 73 -102 .

4. A. L. Payne, "The ecology of tropical lakes and rivers", 1986, J. Wiley and Sons.
5. E. E. Souza Filho and J. C. Stevaux, "Foodplain area of high Parana river. Physical, biological and socioeconomic aspects", ed. A. E. A. M. Vazzoler, A. A. Agostinho, and N. S. Hahn, 1997, EDUEM, Maringá, 3 - 46.

6. R. G. Wetzel and G. E. Likens, "Limnological analyses", 2nd ed., 1991, Springer-Verlag.

7. C. J. Lorenzen, Limnol. Oceonogr., 1967, 12, 343.

8. J. Murphy and J. P. Riley, Anal. Chim. Acta, 1962, 27, 31.

9. I. S. Scarminio and R. E. Bruns, Trends Anal. Chem., 1989, $8,326$.

10. J. D. Allison, D. S. Brown, and K. J. Novo-Gradac, MINTEQA2, "A geochemical assessment data base and test cases for environmental systems", ver. 4.0, Report EPA/600/3-91/-21, 1999.

11. J. P. Gustafsson, VisualMINTEQ, ver. 1.03. KTH, Div. of Land and Water Resources, 2001.

12. S. Train and L. C. Rodrigues, "A foodplain area of high Parana river. Physical, biological and socioeconomic aspects", ed. A. E. A. M. Vazzoler, A. A. Agostinho, and N. S. Hahn, 1997, EDUEM, Maringá, 105 - 115.

13. S. M. Thomaz, M. C. Roberto, F. A. Lansac Tôha, A. F. Lima, and F. A. Esteves, Acta Limnol. Brasil, 1992, 4, 32.

14. H. H. Rump and H. Krist, "Laboratory manual for the examination of water, waste water and soil", 1992, VCH.

15. S. R. G. Barreto, J. Nozaki, and W. J. Barreto, Acta Hydrochim. Hydrobiol., 2004, 31, 513.

16. P. Westerhoff and D. Anning, J. Hydrology, 2000, 236, 202.

17. F. A. de Esteves, "Fundamentals of limnology", 1998, Interciências.

18. R. G. Wetzel, "Limnology", 2nd ed., 1983, Saunders College Publishing.

19. R. I. Jones, Hydrobiologia, 1992, 229, 73.

20. H. Borg, "Trace elements in natural waters", ed. B. Salbu and E. Steinnes, 1995, CRC Press, Inc., 177 - 201.

21. R. J. Gibbs, Science, 1973, 180, 71. 